Article

\title{
Organizational Approaches to the Facilitation of Education for Sustainability: An Interpretive Case Study
}

\author{
Michael S. Duggan *, Timothy F. Smith and Dana C. Thomsen
}

Sustainability Research Centre, University of Sunshine Coast, Locked Bag 4, Maroochydore DC, Queensland 4558, Australia; E-Mails: TSmith5@usc.edu.au (T.F.S.); DThomsen@usc.edu.au (D.C.T.)

* Author to whom correspondence should be addressed; E-Mail: msd010@student.usc.edu.au; Tel.: +61-434-140-069.

Academic Editor: Sara Holdsworth

Received: 2 March 2015 / Accepted: 20 May 2015 / Published: 2 June 2015

\begin{abstract}
The facilitation of Education for Sustainability (EfS) by Decentralized Global Networks (DGNs) is consistent with the dynamic and increasingly complex nature of sustainability issues, and is often motivated by inter-governmental policy objectives that link sustainability learning with sustainable development. The use of DGNs for EfS is now well established and supports the participation of a geographically dispersed and diverse body of participants that consist of teachers, teacher-educators, policy makers, and researchers. However, there is limited understanding of the complex systems operating within DGNs and how these systems generate the conditions necessary to facilitate EfS. In this article, the authors report on an interpretive case study of the Environment and Schools Initiative (ENSI), a DGN operating for over 26 years with a membership that has spanned over 25 countries. Findings highlight six dimensions of the ENSI DGN important to the effective facilitation of EfS including: (1) developing a community of practice; (2) planning for phased organizational development; (3) structured decentralization using a strategy-node-program framework; (4) linking research to practice; (5) ensuring relevance through contextualized approaches; and (6) monitoring and evaluation of processes and outcomes. The findings identify organizational level approaches to EfS facilitation such as addressing the nexus created between policy, practice and research, and developing a structure focused on learning and the development of networks more broadly. In conclusion, the delivery of learning and teaching strategies through a geographically dispersed and diverse group of participants can address the inherent complexity of EfS facilitation across various spatial and cultural scales.
\end{abstract}


Keywords: education for sustainability; community of practice; decentralized global network; facilitation; Environment and Schools Initiative (ENSI)

\section{Introduction}

Increasing recognition of the global and interconnected nature of sustainability issues has given rise to approaches to Education for Sustainability (EfS) that are similarly international in scope and delivery. These approaches use Decentralized Global Networks (DGNs) spanning multiple jurisdictions and geographic boundaries to facilitate EfS programs. The Environment and Schools Initiative (ENSI) commenced in 1986 and is a noteworthy example of a DGN that has connected researchers, teachers, teacher-educators, and policy-makers through the delivery of its EfS programs. The ENSI Organization has included members spanning over 25 countries and research addressing program outcomes has been presented at over 300 conferences and in over 150 EfS documents and published research papers [1-11].

The practice of delivering EfS through a DGN is not isolated to the ENSI case. There are other examples of both more recent and past DGNs with significant histories of facilitating EfS. The Foundation of Environmental Education (FEE), is another important example of a DGN that began facilitating environmental education in 1981 and now delivers EfS programs through 83 members representing 67 countries [12,13]. Together, ENSI and FEE are two of the longest continuously running DGNs that deliver EfS programs internationally [14-16]. Other noteworthy examples include the Center for Ecoliteracy [17] which commenced in 1995 and now delivers programs in over 30 countries; and, the Environmental Education Group which has been facilitating EfS for over 40 years including involvement in the founding of the Earth Day global EfS initiative [18].

The remainder of this article focuses on the interpretive case study of the ENSI DGN. As a DGN, ENSI contributes to activities at local (e.g., school-based EfS), national (e.g., EfS policy development) and global (e.g., international and multi-stakeholder partnerships) scales. While a networked approach promises to overcome difficulties in contextualizing sustainability knowledge across these extensive organizational, cultural and geographic scales and can support regions with limited resources, few studies have been undertaken to explore how a DGN facilitates and supports EfS. As part of a larger study into the practices of DGNs concerned with EfS, this article explores ENSI as a significant case study to determine effective strategies characterizing the delivery of EfS at an organizational level and the complex issues arising from the participation of a geographically dispersed and diverse group of participants comprising a DGN.

\section{Methods}

An interpretive case study approach was used to generate detailed and contextualized data from ENSI at the organizational level. Data was generated iteratively in four sequential phases, namely: (1) observational participation; (2) document analysis; (3) in depth interviews of key informants; and (4) an online survey. The online survey was extended beyond the ENSI membership to include members of FEE to expand on themes generated in earlier phases. Data collection occurred over a period of five years from September 2008 to August 2013 (Table 1). 
Table 1. The Environment and Schools Initiative (ENSI) case study data generation and analysis phases.

\begin{tabular}{|c|c|c|}
\hline Phase & Data source & Analytical approach \\
\hline $\begin{array}{l}\text { 1. Observational } \\
\text { participation } \\
\text { (September 2008) }\end{array}$ & $\begin{array}{l}\text { Executive Meeting/AGM, Berne, } \\
\text { Switzerland, September, } 2008 \text { (ENSI } \\
\text { Executive Committee, Secretariat, } \\
\text { Critical Friends and Project/Country } \\
\text { Managers in attendance). }\end{array}$ & $\begin{array}{l}\text { Identification of key organizational } \\
\text { documents, key informants and } \\
\text { preliminary analytical themes. }\end{array}$ \\
\hline $\begin{array}{l}\text { 2. Document analysis } \\
\text { (September 2008 } \\
\text { to August 2013) }\end{array}$ & $\begin{array}{l}\text { ENSI constitution, strategic plans, } \\
\text { meeting minutes, newsletters, project } \\
\text { proposals, evaluation reports and } \\
\text { research articles. }\end{array}$ & $\begin{array}{l}\text { Qualitative content analysis utilizing } \\
\text { NVivo to establish the operating contexts } \\
\text { of ENSI including organizational } \\
\text { governance structures and } \\
\text { program delivery processes across } \\
\text { geographical, organizational, } \\
\text { and cultural dimensions [19]. }\end{array}$ \\
\hline $\begin{array}{l}\text { 3. Key informant } \\
\text { interviews } \\
\text { (conducted via } \\
\text { Skype) } \\
\text { (February 2012 } \\
\text { to April 2012) }\end{array}$ & $\begin{array}{l}\text { Nine of ENSI's organizational leaders } \\
\text { (Executive, Country Coordinators, and } \\
\text { Critical Friends) including those based } \\
\text { in Europe and Australia. }\end{array}$ & $\begin{array}{l}\text { Deductive thematic analysis using eight } \\
\text { themes derived from phase 2, namely: } \\
\text { (1) accountability to stakeholders; } \\
\text { (2) network development; (3) roles in EfS } \\
\text { facilitation; (4) governance structure; } \\
\text { (5) network democracy; (6) relevance to } \\
\text { participants; (7) complexity of the } \\
\text { learning network; and (8) scalability. } \\
\text { Data was coded using NVivo and } \\
\text { relationships between codes were } \\
\text { validated using Leximancer. }\end{array}$ \\
\hline $\begin{array}{l}\text { 4. Survey } \\
\text { (May } 2013 \text { to } \\
\text { August 2013) }\end{array}$ & $\begin{array}{l}\text { Online survey questionnaire of } \\
\text { organizations representing over } \\
60 \text { countries and 1000's of members. } \\
\text { The survey recipients were identified as } \\
\text { facilitators of EfS at a leadership and/or } \\
\text { project manager level through their roles } \\
\text { as members and/or affiliates of the ENSI } \\
\text { and FEE DGNs. } 13 \text { organizations } \\
\text { provided responses to the survey. }\end{array}$ & $\begin{array}{l}\text { The survey extended and deepened } \\
\text { insights generated in the first three phases } \\
\text { and focused on the approaches to } \\
\text { facilitating EfS at multiple scales applied } \\
\text { by DGNs at an organizational level. }\end{array}$ \\
\hline
\end{tabular}

Thematic analysis of data generated in Phases 1 (Observer participation) and 2 (Document analysis) was combined with a review of the related literature across the fields of EfS, DGN, scalability, globalization and monitoring and evaluation to establish a code manual grounded in the established theory and practice of EfS and the specific contexts of ENSI. Key themes were deduced through a 6 stage process of codification resulting in the code manual identifying and describing 8 overarching themes (Table 1), and 54 more detailed sub themes [20]. This process provided a consistent structure for the generation and analysis of interview data (Phase 3) and ensured congruence between the theory and dynamic practices of EfS. 
Following a standardized interview process based on the 8 themes, analysis of interview transcripts was conducted using the analytical software packages NVivo and Leximancer. NVivo was used to explore the established themes in more detail and to identify any novel or emerging sub-themes. Leximancer was then used to establish the existence and strength of relationships between themes/ sub-themes. This approach improved the methodological rigor through the development and demonstration of a path of analytical evidence and analysis maintained throughout the research process [21].

The application of NVivo and Leximancer resulted in 54 sub themes and detailed, rich insights into the experiences of key informants in the facilitation of EfS at the organizational and program levels. These findings were subsequently used as the basis for an online survey of ENSI and FEE members to gain broader insights into the applicability of these findings across the network and similar organizations. Interview responses support data collected throughout the document analysis phases and are referenced in 22 instances throughout this paper. Survey responses are used to support specific statements provided by respondents and are referenced 8 times in addition to being presented in more detail in the tables presented here within. The survey response rate was 22\%. Although this does not represent a high response rate, the characteristics of respondents are representative of the wider sample across the two dimensions central to this study (i.e., DGN membership and facilitation of EfS) [22-24].

All data generated through the interviews and survey described in Table 1 was de-identified and referenced throughout the body of the article. Interviewees were referred to by data type and number (e.g. Interviewee \#1) within the reference section to ensure the anonymity of responses.

\section{Results and Discussion}

The findings reveal six dimensions, relevant at the organisational level, which enhance the delivery of EfS through a DGN including: (1) developing a community of practice; (2) planning for phased organizational development; (3) structured decentralization using a strategy-node-program framework; (4) linking research to practice; (5) ensuring relevance through contextualized approaches; and (6) monitoring and evaluation of processes and outcomes. The findings indicate that since ENSI commenced as an Organization for Economic Cooperation and Development (OECD) initiative in 1986, the incorporation of these six dimensions into organizational structure, strategy and on-going development has supported substantial achievements in the delivery of EfS over 26 years of continuous operation. In particular, ENSI has delivered fifteen major EfS projects with individual project budgets in excess of $€ 50,000$ and involving over a thousand teachers and schools located in over 25 countries $[1-11,25]$. ENSI was recognized as having a wider applicabilty to the discipline of EfS internationally through the early leadership role taken as a key contributor to identifying the progress and possibilities for the United Nations Decade of Education for Sustainable Development (UN-DESD) in European Union member states [26]. In addition, ENSI has influenced the agendas of national governments by providing key inputs to the development of international EfS policy, such as that of European countries (e.g., Hungary

and Italy) where ENSI played a crucial role in the process of integrating EfS and Environmental Education (EE) as a core component of the national curriculum [1]. 


\subsection{Developing a Community of Practice}

Consistent with the guiding intent of ENSI's strategic plan, the interests of the ENSI community developed dynamically and often arose from sharing lessons across diverse spatial and cultural contexts [27]. ENSI identified itself as a "community of practice (CoP) for research, development and innovation exchange in the field of environmental education and education for sustainable development (EfSD)" [28] (p. 5). As highlighted by one participant, "a main strength [of ENSI] was the sharing of information across participating countries...learning a great deal about what others were doing” [29]. Similarly, another participant identified that ENSI fostered relationships and community-building by "bringing people together from all sorts of organizatons in an inclusive nature" [30]. True to the nature of a CoP ENSI was characterized by participants' interactions and engagement regarding shared concerns, challenges and passion for a particular topic [31-33]. In ENSI's case this “topic” was EfS and engagement was facilitated through the international exchange of experiences (i.e., programs) grounded in environmental understanding, dynamic qualities of EfS and active approaches to teaching and learning [34]. The importance and interpersonal significance of these relationships and shared experiences was reinforced by one interviewee who likened the ENSI DGN to a family “...we say at ENSI it is like a family so the friendship and the openness of ENSI colleagues and the very good human connections and relationships are very important” [35]. Consistent with ENSI’s organizational strategy, survey respondents ranked the establishment of a CoP as the most important role performed by a DGN from the options provided (Table 2).

Table 2. Survey respondent perceptions of the most important roles of a Decentralized Global Network (DGN).

\begin{tabular}{cc}
\hline Potential DGN Role & Rank $*$ \\
\hline Establishing a community of practice & 1 \\
Creating learning networks & 2 \\
Linking theory with practice & 3 \\
Educating others in EfS faciliation & 4 \\
Providing structure through Administration & 5 \\
Advancing the body of knowledge for EfS & 6 \\
\hline
\end{tabular}

* A ranking of 1 indicates the role considered most important and 6 least important.

In explaining the allocation of rankings, survey respondents identified various organizational functions that further serve to illustrate the essential, but diverse roles of a CoP in the ENSI DGN. For example, a CoP was described as: the "backbone” of a DGN (Survey Question 1, Respondent \#1); addressing the challenges of communication; providing support that was limited or lacking in particular contexts; and as a way of integrating more broadly with communities. These findings highlight the importance of developing a $\mathrm{CoP}$ in conjunction with an enduring organizational structure, a focus on learning, and the development of networks more broadly.

The ENSI strategic plan and previous research considering ENSI's key roles identified the development of stable learning networks and cooperative linking of participants (e.g., teachers to schools, and communities to workplaces) as key strategic objectives [15,27,34]. Correspondingly, the creation of learning networks was identified as the second most important role by survey respondents 
(Table 2). Analysis of both interview and survey data demonstrated a close relationship between learning networks and CoPs with one respondent indicating that “...these functions are interconnected and interdependent” (Survey Question 2, Respondent \#5). Learning networks were formed within the ENSI $\mathrm{CoP}$ as a result of collaborative and experiential learning communities that consisted of participants connected to each other through personal and/or program objectives [36]. Whilst ENSI's CoP was more broadly structured, less formal and regulated, its learning networks were more institutionalized and established to support specific ENSI program objectives [37]. The interactions occuring within the CoP were likely to be significantly structured by the identified areas of interest and formal controls of its participants (i.e., organizations, individuals and government bodies) where, for example, those participants represent the policy and research interests of differing member countries [38]. Learning networks played a supporting role in the development of the ENSI CoP linking network structure (i.e., programs) and participants around a sense of common learning [39], a relationship that was generally supportive of ENSI's facilitation of EfS.

The ranking of roles (Table 2) associated with connection, collaboration and community were identified as of higher importance to a DGNs facilitation of EfS than, for example, the administration of the network itself or the broader outcomes delivered by the facilitation of EfS, such as, advancing academic knowledge. This result indicates that the ENSI DGN considered network-wide achievement, learning and the creation of a common identity [40] as of most importance to the facilitation of EfS. This assertion is supported by the survey data, indicating the importance placed on facilitating communication and a network structure grounded in expertise, interests, common learning and a sense of network identity [40,41]; as well as, through its engagement processes regarding collective concerns, challenges and passion for a particular topic [32,33,42] shared amongst the participants. The ENSI case demonstrates that "the creation of a community generates a strong incentive and motivation [to facilitate EfS]” (Survey Question 3, Respondent \#6). ENSI’s implementation of learning networks linking participant interests to relevant EfS research problems (e.g., quality criteria, learning environments, etc.) is supportive of literature identifying CoPs as well-established mechanisms through which to provide structure for educational programs grounded in expertise, interests, common learning and a sense of network identity $[40,41]$.

\subsection{Planning for Phased Organizational Development}

ENSI was established at a time when the need was identified to fill a gap in education and learning by addressing EfS and EE at a school-community level [43]. The OECD identified that an organization or program had not yet been established in Europe that addressed these areas together so they launched ENSI, encouraged their members to engage with the development of the evolving CoP and then allowed ENSI's governance structure to emerge unabated in it's early phases [43]. ENSI was encouraged by the OECD to remain steadfast in its objectives to align environmental education and EfS with the concepts of initiative, independence, commitment and, for example, a readiness to accept responsibility [15]. ENSI did, however, revise it's strategy a number of times throughout the first fifteen years of its operation implementing a significant strategic alignment process in 2005 as it entered a new phase of organizational delivery [3]. In the mid-1990's ENSI was transformed from a sponsored project to an 
independent organization and, despite this significant evolution, did not deviate from its founding objectives [14].

Understanding the ENSI Organizations development cycle was important to examining the dimensions through which it has facilitated EfS at an organizational level, as evidenced by a participants comment:

I think...ENSI...has changed so dramatically in the three phases. The first phase was cutting edge, action research...you know leading in that area. The second stage was (where) we tried to influence policy and sort of up-scale the good practice; and, the third one was just a group of people coming together and sharing resources [44].

The "Waves of Development" (Table 3) recognized the importance of ENSI's history of phased development to its current organizational delivery and how the network has evolved since its inception [1,14]. Each phase, or "Wave" as it has been presented, in ENSI's history provided significant learnings regarding the changing strategic contexts and geo-political conditions in which the organization was required to navigate.

Table 3. ENSI's Four Waves of Development.

\begin{tabular}{|c|c|}
\hline $\begin{array}{c}\text { ENSI Wave of } \\
\text { Development }\end{array}$ & Characteristics \\
\hline $\begin{array}{l}\text { The First Wave: } \\
\text { Establishment } \\
\text { (1986-1988) }\end{array}$ & $\begin{array}{l}\text { - OECD (CERI) proposal submitted and accepted in } 1985 . \\
12 \text { members from OECD countries join network in } 1986 . \\
\text { - Over } 65 \text { schools involved in projects/research representing } \\
\text { over } 20 \text { countries. } \\
\text { - Over } 145 \text { teachers/teacher educators participating. } \\
\text { - Focusing on linking project development and academic research. } \\
\text { - Commencing membership fees and project funding/grants sustain } \\
\text { the organisation. }\end{array}$ \\
\hline $\begin{array}{c}\text { The Second Wave: } \\
\text { Consolidation } \\
\text { (1989-1994) }\end{array}$ & $\begin{array}{l}\text { - OECD (CERI) defined ENSI as a full project for the period } 1989 \text { to } \\
\text { 1994. } 10 \text { more OECD members join ENSI. } \\
\text { - Over } 135 \text { schools involved in projects /research representing } \\
\text { over } 25 \text { countries. } \\
\text { - Over } 765 \text { teachers/teacher educators participating. } \\
\text { - Involved in policy review, action research, and EfS evaluation } \\
\text { projects (e.g., Sustainable Development in the Netherlands). } \\
\text { - Commencing and continuing membership fees and project } \\
\text { funding/grants sustain the organisation. }\end{array}$ \\
\hline
\end{tabular}


Table 3. Cont.

\begin{tabular}{|c|c|}
\hline $\begin{array}{c}\text { ENSI Wave of } \\
\text { Development }\end{array}$ & Characteristics \\
\hline $\begin{array}{l}\text { The Third Wave: } \\
\text { Expansion } \\
(1995-2004)\end{array}$ & $\begin{array}{l}\text { - ENSI concludes as an OECD (CERI) project (1994) and commences } \\
\text { - } \text { Os an independent network under the OECD umbrella. } \\
\text { over } 25 \text { countries. Some members leave ENSI. } \\
\text { - Over } 2740 \text { teachers/teacher educators participating. } \\
\text { - Commenced a network development and decentralisation phase } \\
\text { including scaling out projects to other regions/countries } \\
\text { more actively. } \\
\text { - Commencing and continuing membership fees and project } \\
\text { funding/grants sustain the organisation. }\end{array}$ \\
\hline $\begin{array}{l}\text { The Fourth Wave: } \\
\text { The Decade } \\
\text { (2005-2014) }\end{array}$ & $\begin{array}{l}\text { ENSI prepares } 5 \text { Year Strategic Plan (2006-2010) and implements } \\
\text { active 'Regionalisation/ Decentralisation' program. OECD (CERI) } \\
\text { ceases role as umbrella organisation. UNESCO/UNECE/UNEP } \\
\text { commence as ENSI partner. } \\
\text { - ENSI contributed in the early stages to the development of the } \\
\text { UN-DESD. In the following years they both scaled-out and back in } \\
\text { their projects . They amended their organisational structure and } \\
\text { witnessed a decline in both active projects and Country membership. } \\
\text { - ENSI transitions its DGN in } 2009 \text { to an International Non-Profit } \\
\text { Association (INPA), a legal and governance structure under Royal } \\
\text { Belgian Decree, that afforded them the ability to maintain } \\
\text { both a decentralised network and program delivery } \\
\text { organizational structures. } \\
\text { Fee for Service/online collaboration models introduced to augment } \\
\text { membership fees and project grant funding. } \\
\text { In 2005, } 24 \text { countries were ENSI members. By late-2013, this } \\
\text { number had reduced to } 19 \text { countries with } 10 \text { representing full-fee } \\
\text { paying membership. }\end{array}$ \\
\hline
\end{tabular}

ENSI's transition between waves was facilitated by an on-going process of strategic development addressing issues related to its partners and regional networks [1]. ENSI concentrated on "reinventing themselves every three or four years" [44] ensuring organizational and program objectives and renewed strategy aligned to current local and global priorities (e.g., relevance to participants). As supported by a participant's response:

ENSI had to follow a clear strategy by following clear research questions which arise through the years in environmental education [45].

Organizational development has been dynamic and "the [ENSI] influence and the power has changed quite dramatically over the years” [44]. For example, the transition from wave one to wave two in ENSI's development was characterized by a scaling up (i.e., organizationally) and out (i.e., geographically) of programs and membership [19]. ENSI “refocused on key priorities" and questions at planned 
intervals [44] and envisioned this process of continuous organizational development as occurring through the adoption of clear research direction and objectives [27].

The historical development and evolution of ENSI demonstrates a "complex and systemic approach” [46] to phased development and the impact upon organizational structure, governance, strategy, systems and multiple functional connections as the organization matures and enters/exits cycles of growth and decline [47]. These organizational developments impacted upon ENSI's facilitation of EfS as is evidenced throughout the fourth wave, which is characterized by ENSI's most significant change in structure and corresponding decline in membership and participants. ENSI's structured approach illuminates the importance placed by the OECD and ENSI Leaders upon the organization being resolute in its strategy-oriented approach from the outset, yet flexible enough to be able to revise and self-regulate strategy throughout the years in order to transition between development phases. Changing influence and power at local and global scales required ongoing re-development of strategy to accommodate differing development phases [19]. ENSI's organizational documents chronicle this phased development and the longevity of the organization lends credence to the success of it's approach as it relates to organizational delivery [1-11,48]. The application of an entrepreneural approach towards meeting organizational goals and towards changing organizational contexts [49] is an approach evidenced by the ENSI case and demonstrates the importance of DGN more generally planning for the challenges and impacts of transitioning between development phases given the complex systems of interconnections that comprise the process in which they deliver EfS over longstanding periods of time [50].

\subsection{Structured Decentralization Using a Strategy-Node-Program Framework}

ENSI's approach to connecting EfS research, practice and policy-making was to apply a framework of structured decentralization that ensured the organisation met its aim to create stable, yet dynamic, learning networks, generate local knowledge and meaningful discourse and foster democratic participation [34]. For ENSI, the structured approach to decentralization was reliant upon the development of regionalised learning networks established through local partnerships and alliances [27] which link schools, families, community, and workplaces together [43]. Participants indicated that ENSI's application of a "regionalized” approach supported its faciliation of EfS:

ENSI got all of that right. It's a global organization that works through the regions at a local level... as well as the change in this area at a very practical level. It is about supporting a true regional outlay but on a global level. It's a fantastic example of a decentralized network [44].

As indicated in Section 3.1, ENSI facilitated the formation of a CoP to connect participants more broadly and informally to the organization. Learning networks were formed at the program level to provide for a more formal network structure [38]. As such, all ENSI participants were members of both the organizational $\mathrm{CoP}$ and those specific learning networks formed at the program scale grouping themselves around particular program objectives, themes and participant interests [48].

ENSI adopted an decentralizied approach to facilitating learning and participation that made a concerted effort to engage the CoP and its collection of learning networks in simultaneous bottom-up and top-down methods of governance facilitated by a central hub linked closely to each regional node (Figure 1). As summarised in the following quotation from a participant "[ENSI] is an international 
network...development network, point of reference, something that we learn from the international community and we also contribute to" [45]. By identifying the DGN and its principles as a "point of reference" for participants and the broader community, ENSI's decentralized approach aided the translation of centrally developed strategy into contextualized understanding and practice at a local level $[1,14]$ utilizing the regional nodes to translate strategic aims into program objectives [34].

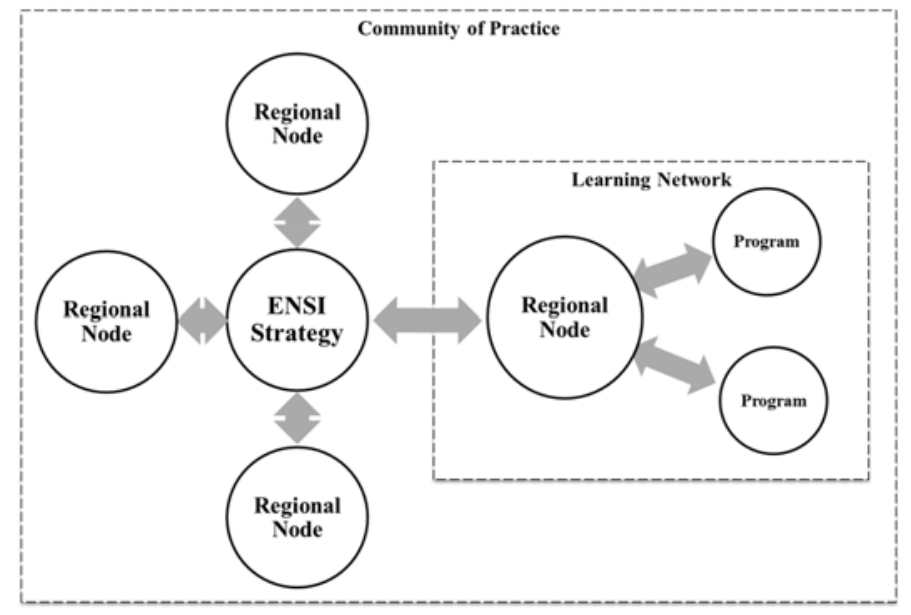

Figure 1. The decentralized global network’s strategy-node-program framework.

The implementation of a strategy-node-program framework as a means to faciliate EfS is a feature unique to ENSI. For example, there are tens of thousands of civic networks active internationally [51] and, whereas, these types of global social change networks are not dissimilar in some aspects to the structure of ENSI in that they are non-hierarchical and decentralized, they are often loosely organized across the organization and accountability is highly diffuse [52]. In contrast, ENSI demonstrates an approach to network decentralization that engaged members in a manner that is both flexible (i.e., CoP) and structured (i.e., learning networks) [27,32]. The approach involved the adoption of a center of power (i.e., ENSI Secretariat and Executive) that set the broad strategic direction for the network, but ensured that the regionalized nodes the CoP was comprised of were free to self-organize through program delivery and were accountable for their work at the local level [34]. ENSI achieved this by enacting a formal structure to ensure the organization addressed participant interests in an inclusive and democratic manner including, procedural requirements such as setting the annual strategic direction for the organization each year at the Annual General Meeting (AGM) [27]. The decentralized model included at each regional node a Country Coordinator to manage the connection between organizational strategy and programs, and an Academic Representative providing pedagogical support to the program managers. The Coordinator and Academic Representative were entrusted with the overall coordination of ENSI programs aligned to strategic organizational objectives, however, they were encouraged to contextualize approaches for regional priorties and facilitate EfS through, for example, the regions schools and/or wider educational curriculum [27]. ENSI's approach to decentralization provided autonomy to the Country Coordinator and Academic Representative to operationalize at the program level (i.e., the learning network) strategy developed at the more central level. Whereas a failure of decentralization could be attributed to a lack of understanding of how to effectively participate because of norms associated with traditional societal hierarchies [53], ENSI's decentralized framework afforded 
participants the opportunity to remain accountable to organizational objectives whilst encouraging wide-ranging opportunities to individualize participation in the DGN.

ENSI's approach supported the development of dynamic learning networks which are non-hierarchical, flexible and supportive of the establishment of professional exchange [54]. A success of ENSI has been atributed to its position as an interface between the learning networks constructed and the more hierarchial networks of its participants (e.g., schools and government) [48]. The formation of learning networks embedded within the ENSI framework complement and to some extent act as a substitute for hierarchial networks [55]. ENSI recognized that the regionalized and structured approach to decentralization that occurred through the formation of learning networks was an effective tool in which to deliver EfS within diverging systems and has been identified throughout the field's literature [56,57] as applying an approach that effectively links decentralization to democratic process $[32,53,58]$ an important aspect of EfS delivery [56,59]. An improved understanding of the nature of a structured and decentralized approach is timely as the United Nations Educational, Scientific and Cultural Organization (UNESCO) recently acknowledged that greater decentralization characterised by a flexibile and autonomous approach increased the likilhood that EfS initiatives and projects were to be adopted [59].

\subsection{Linking Research to Practice}

ENSI's approach to the facilitation of EfS connected the development of ideas and insights to implementation tools and structures that enabled EfS programs to facilitate realistic practices [60]. ENSI supported theoretical notions coupled with practical experiences through the implementation of joint research and action [50] and set about fostering research-community-school collaboration through the assembly of inter-agency networks crossing traditional boundaries between research centers, government, interest groups and learning organizations [61]. Through the application of this approach ENSI connected teachers, teacher-educators, policy makers and research groups together supporting the link between these dimensions. ENSI's strategic planning documented these synergies as primary to the DGNs organizational objectives [27,35].

ENSI was identified (i.e., pre-2000) as the only international research network with a primary aim of connecting research and government authorities with school practices [1]. A participant described this approach as establishing a "triangle of policy, practice and research which is a really good marriage" [30]. ENSI's approach rejected the assumption that there should be a traditional separation between school and society in favor of connecting these dimensions through open and experiential questioning and shared interests [58]. As indicated by one respondent "this kind of interface of teachers whom are highly engaged in their school projects with governmental people engaged in national programs, and with researchers trying to find out how to improve EfS and EE programs makes up the strengths of ENSI” [42]. Participants indicated that it was of key importance to the ENSI Organization that it maintained the interface across a number of levels of research and government in the specific field of environmental education and EfS [45,62]. ENSI's role in this process included what one participant refered to as advancing:

...the policy of education, the practice of education, the teacher in the school and the research

... to be a kind of bridge between the realities that in many cases don't work together [63]. 
ENSI's leaders described how the DGN would engage with its network to connect its broad membership together around clear research-practice questions as follows.

... the strategy was to always have an ear into the real national programs and then to reflect what exactly the open questions are. And, then to bring these open questions into the network of researchers and government authorities to find out what are the most important questions we have to deal with today [45].

To facilitate this "bridge" ENSI positioned itself to "influence the development of national programs" [45] through a membership base that was primarily composed of government representation partnering with the ENSI organization to assist in influencing local EfS curricula at departmental and government levels [1,34]. This approach was acknowledged by government authorities (e.g., Austria, Germany, Italy) as being integral to the establishment and mainstreaming of EfS programs in their schools [1].

ENSI was cognizant that "in order to create good practices it was important to link knowledge with practice” (Survey Question 2, Respondent \#7) and recognized that addressing the nexus created between research and practice was a fundamental aspect of their facilitation of EfS, as reflected in the response of this participant:

The biggest challenge of ESD (Environmentally Sustainable Development) is to transform ambitious theories into practice. There is huge need to help practitioners to develop practices, theoretically well-established practices, which fit into the reality of everyday educational practice (Survey Question 2, Respondent \#8).

The translation of conceptual understanding and research into opportunities to put learnings into practice remains a key factor of success in the linking of people and organizations to local and global sustainability goals [64]. ENSI's approach of linking research to practice contributed to an improved understanding of what is referred to as clear researcher-practitioner collaborations [65], whereby, the researcher and practitioner may not view the research process in the same way, however, they are able to harness this tension to meet program objectives [66]. The complexity of this process highlights the importance of DGNs translating strategic and research objectives into EfS policies and practices as a key component of EfS facilitation.

\subsection{Ensuring Relevance through Contextualized Approaches}

ENSI's approach to delivering programs across temporal, spatial and cultural scales necessitated that the facilitation of EfS was contextually relevant to accommodate the multiplicity of cultures and participants comprising the DGN. Relevance to individual and wider community concerns and sustainability issues was recognized as a central principle of conducting EfS across these dimensions [67]. Embedding contextually in ENSI's approach to EfS has been recognized in previous research [54] and is highlighted as an innovation by ENSI itself [68]. A focus on context-specificity ensures that ENSI recognises the need to empower schools, teachers, and researchers to ensure equality in the planning and delivery of programs that are framed in connection with, as opposed to in isolation of, the wider society and local contexts [68]. 
The framework and approaches identified in Sections 3.3 and 3.4 establish a collaborative arrangement between participants across varying scales. ENSI adopted the approach of developing a different project in differing countries and regions [1] to accommodate local contextual requirements, encourage relevance to participants' objectives and to maintain consistency with organizational goals, as highlighted by the following response.

... they [ENSI] reinvent themselves...they refocus key priorities and they always make sure they are linking relevance to, for example, government policy [44].

Participants recognized that relevance "makes it (EfS) practical and leads to a greater commitment and long term involvement” (Survey Question 14, Respondent \#2). Correspondingly, survey responses supported the perceived importance of relevance to a DGNs facilitation of EfS (Table 4).

Table 4. Survey respondent perceptions of the most important aspects of a DGNs culture and values to the facilitation of EfS.

\begin{tabular}{lc}
\hline \multicolumn{1}{c}{ Role } & Rank * \\
\hline $\begin{array}{l}\text { Relevance to the stakeholders that both deliver and experience the facilitation of EfSD } \\
\text { to ensure the attraction and retention of organization members and project participants. }\end{array}$ & 1 \\
\hline $\begin{array}{l}\text { Accountability to key stakeholders including, but not limited to, project/organization } \\
\text { funders, research participants, and organizational staff. }\end{array}$ & 2 \\
\hline Democratic organization whereby all members have a say. & 3 \\
\hline $\begin{array}{l}\text { Monitoring and evaluation systems } \\
\text { in place to evaluate meeting EfSD facilitation goals and objectives. }\end{array}$
\end{tabular}

* A ranking of 1 indicates the role considered most important and 4 least important.

In referring to ENSI's programs a participant indicated that when it came to EfS programs “...one size does not fit all” (Survey Question 12, Respondent \#5). ENSI aligned objectives to participant motivations for connecting to the network from the outset through establishing relevance, an important construct, as it was identified that “...initiatives that lack relevance to multiple partners will engender low commitment levels and are more likely to have a short life span” (Survey Question 14, Respondent \#1).

ENSI addressed relevance through a contextual and research led, in contrast to, a content focused approach. "(ENSI) was not dedicated on the content such as air pollution, it was more dedicated on the questions that arose through collaboration with pilot schools in the regions” [45]. A contextualized approach provided ENSI the opportunity to reframe programs to address varying participant requirements by embedding consistent research questions within diverse content. By way of example, ENSI's Learnscapes program addressed the question of "how students learnt by doing” through interactions in differing outdoor environments (i.e., Learnscapes). The Learnscapes were constructed to meet cultural or spatial demands and were vastly different located in, for example, Australia and across European countries. The research questions remained the same (i.e., how students learn) and could be posed to participants regardless of varying contextual requirements. An appreciation of the differing contextual needs, driven by differing physical environments is vital if programs delivered by DGN are going to function across spatial and cultural boundaries. 
ENSI's contextualized approach to EfS programs addressed the increasingly global nature of EfS facilitation, including the reframing, as opposed to reforming, of information and knowledge so that it can be understood from multiple frames of reference [69]. In this way, contextualization accommodated shared EfS goals, values and engendered a common vision [70]. ENSI delivered programs that catered for a range and variety of individual and locally determined needs. The significance of which is supported by literature which identifies that implementing EfS programs without taking due care for an understanding of contemporary society and culture, or paying only cursory attention to local context or relevance to participants, may limit rather than foster approaches to, and perspectives of, EfS [71-73].

\subsection{Monitoring and Evaluation of Processes and Outcomes}

ENSI's monitoring and evaluation strategy was established as an OECD Centre for Educational Research and Innovation (CERI) requirement at the outset of the Organizations development [74]. CERI recognized that, in general, DGNs funding should be directed towards evidence-based programs and the importance of scaling the impact of these programs should be addressed [75]. Formal evaluation was incorporated into ENSI's delivery of programs by requiring participants to report back progressively to the Program Manager and/or Country Coordinator regarding advancement towards organizational and program objectives. These "reports" were in turn evaluated by the ENSI Executive annually at the AGM [48]. CERI established this process to ensure ENSI members were accountable for the preparation of evaluation reports upon program completion and that these reports could be utilized by both ENSI and CERI to improve upon organizational delivery, to monitor progress toward program objectives and to influence the further development of ENSI [48]. ENSI's support for this approach was substantiated through a dedicated section of their most recent strategic plan focusing upon progress reviews and ongoing evaluation processes [27].

Interview respondents supported ENSIs approach to monitoring and evaluation identifying the importance of evaluation frameworks to ENSI's strategy as highlighted by the following participant's response:

I think the networks that have been strategic have done very well and strategic means rethinking, reviewing, engaging, constantly rethinking what you need to do better, but also what you need to do different [44].

Previous ENSI research supported the importance of regularly discussing, reflecting and debating processes and delivery of program outcomes [14]. Further justification for ENSI's approach to evaluation was made evident through ENSI's influence as an early contributor to the monitoring and evaluation review process UNESCO enacted to inform its global reporting strategies (Interviwees \#4 and \#6). However, although considered important, interview responses also indicated that the need to manage limited resources, both human and financial, provided ENSI's organizational leadership with a difficult task as “...we are always fighting for money...” [63] for program delivery in order to "stay afloat”, as opposed to delivering robust monitoring and evaluation processes [62,76].

The monitoring and evaluation processes that ENSI embedded within its organization are accepted by participants as an integral part of EfS facilitation in general [74]. However, the findings demonstrate disparity between the perceived importance stakeholders place upon monitoring and evaluation 
processes in general and the actual importance to facilitation of EfS they attribute to these processes. These findings have significant implications for DGN more generally as the growing body of research in the area [77-83] suggests that the implementation of monitoring and evaluation and indicator frameworks to EfS facilitation, and sustainability in general, will continue to gain in importance and the significance of the implementation of these frameworks should certainly not be marginalized.

\section{Conclusions}

The facilitation of EfS through DGNs is a well-established practice. The findings identify the characteristics of the ENSI DGNs operation at an organizational scale including an evaluation of the structure, conditions and motivation required to facilitate EfS. In addition, the approach taken towards addressing the nexus created between policy, practice and research was implicated as important to the ENSI DGNs facilitation of effective EfS as the approach addresses the complexity inherent within the delivery of EfS across multiple scales. The article addresses the importance of monitoring and evaluation to inform both the effectiveness and processes underpinning EfS, and to assist DGN more generally to identify the conditions necessary for EfS facilitation to be effective. However, several constraints to the implementation of robust monitoring and evaluation were evident (e.g., funding and time) and these constraints warrant further investigation. Particularly, at the juncture when scaling EfS has been identified as a global priority in UNESCOs DESD Final Report [59] and the supporting document “Roadmap for Implementing the Global Action Program on Education for Sustainable Development” [84]. The article contributes to the body of knowledge relating to organizational approaches to EfS facilitation that are both global and regional and located across various spatial and cultural scales.

\section{Acknowledgments}

The authors acknowledge the contributions of the Environment and School Initiative (ENSI) and the research support provided by the Faculty of Arts and Business and the Sustainability Research Centre at the University of the Sunshine Coast, Queensland, Australia.

\section{Author Contributions}

Michael S. Duggan, Timothy F. Smith and Dana C. Thomsen conceived/designed the methods and contributed materials/tools to the process of analysis; Michael S. Duggan collected the data and conducted the analysis; Michael S. Duggan, Timothy F. Smith and Dana C. Thomsen wrote the paper with Michael S. Duggan the primary author.

\section{Conflicts of Interest}

The authors declare no conflict of interest.

\section{References and Notes}

1. Smith, S. The Role of Environment and School Initiatives (ENSI) in a Global Environment: A Summary of Its Operations, Effectiveness, Relevance and Performance since Its Inception in 1986; Environment and Schools Initiative: Giessen, Germany, 2004. 
2. Environment and School Initiative (ENSI). ENSI Annual Reports 2004; ENSI Secretariat and Executive: Vienna, Austria, 2004.

3. Environment and School Initiative (ENSI). ENSI Annual Reports 2005; ENSI Secretariat and Executive: Vienna, Austria, 2005.

4. Environment and School Initiative (ENSI). ENSI Annual Reports 2006; ENSI Secretariat and Executive: Vienna, Austria, 2006.

5. Environment and School Initiative (ENSI). ENSI Annual Reports 2007; ENSI Secretariat and Executive: Budapest, Hungary, 2007.

6. Environment and School Initiative (ENSI). ENSI Annual Reports 2008; ENSI Secretariat and Executive: Vienna, Austria, 2008.

7. Environment and School Initiative (ENSI). ENSI Annual Reports 2009; ENSI Secretariat and Executive: Brussels, Belgium, 2009.

8. Environment and School Initiative (ENSI). ENSI Annual Reports 2010; ENSI Secretariat and Executive: Brussels, Belgium, 2010.

9. Environment and School Initiative (ENSI). ENSI Annual Reports 2011; ENSI Secretariat and Executive: Mannedorf, Switzerland, 2011.

10. Environment and School Initiative (ENSI). ENSI Annual Reports 2012; ENSI Secretariat and Executive: Vienna, Austria, 2012.

11. Environment and School Initiative (ENSI). Available online: http://www.ensi.org/ (accessed on 12 December 2014).

12. Foundation for Environmental Education (FEE). Eco-Schools Programme: Celebrating 15 Years; FEE: Copenhagen, Denmark, 2010.

13. Foundation for Environmental Education. Available online: http:/www.fee-international.org/ en/menu/members (accessed on 29 May 2015).

14. Lupele, J.K. Networking: Enabling Professional Development and Institutionalisation of Environmental Education Courses in Southern Africa. Ph.D. Thesis, Rhodes University, Grahamstown, South Africa, April 2007.

15. Posch, P. The Project: Environment and School Initiatives; Organization of Economic Cooperation and Development: Paris, France, 1998.

16. Foundation for Environmental Education. Our history. Available online: http://www.feeinternational.org/en/menu/our-history (accessed on 29 May 2015).

17. Center for Ecoliteracy. Available online: http://www.ecoliteracy.org/about-us/what-we-do (accessed on 12 December 2014).

18. Environmental Education Group. Available online: http:/www.green2gold.org/environmentaleducation-group-40-year-history (accessed on 12 December 2014).

19. Duggan, M.S.; Smith, T.S.; Thomsen, D.C. Scaling Sustainability Learning: Size and Scope Matter. J. Educ. Sustain. Dev. 2013, 7, 1-15.

20. Crabtree, B.; Miller, W. A template approach to text analysis: Developing and using codebooks. In Doing Qualitative Research; Crabtree, B., Miller, W., Eds.; Sage Publishing: Newbury Park, CA, USA, 1999; pp. 163-177.

21. Koch, T. Establishing rigour in qualitative research: The decision trail. J. Adv. Nurs. 1994, 19, 976-986. 
22. Dey, E.L. Working with Low Survey Response Rates: The Efficacy of Weighting Adjustments. Res. High. Educ. 1997, 38, 215-226.

23. Dillman, D.A. The design and administration of mail surveys. Annu. Rev. Sociol. 1991, 17, 225-249.

24. Sheik, K.; Mattingly, S. Investigating non-response bias in mail surveys. J. Epidemiol. Commun. Health 1981, 35, 293-296.

25. Posch, P. Environment and School Initiatives: The State of National Developments, A Short Survey. In ENSI Publication; ENSI, Ed.; Austrian Federal Ministry of Education, Science and Culture: Vienna, Austria, 2001.

26. Mulà, I.; Tilbury, D. Progress and Possibilities for the UN Decade of Education for Sustainable Development in EU Member States: An ENSI Report; ENSI Secretariat: Cheltenham, UK, 2009.

27. Environment and School Initiative (ENSI). ENSI Strategic Plan 2006-2010: Supporting a Sustainable World through Education in Schools; ENSI Secretariat: Vienna, Austria, 2005.

28. Environment and School Initiative (ENSI). ENSI Annual Reports 2004 Review; ENSI Secretariat and Executive: Giessen, Germany, 2004.

29. Interviewed by Michael Duggan. Brisbane, Australia. Skype Interviewee \#17 of ENSI Project Manager/Curriculum Coordinator. 17 February 2012.

30. Interviewed by Michael Duggan. Brisbane, Australia. Skype Interviewee \#3 of ENSI Country Coordinator. 1 February 2014.

31. Cox, A. What are Communities of practice? A critical review of four seminal works. Available online: http://www2.warwick.ac.uk/fac/soc/wbs/conf/olkc/archive/oklc5/papers/e-4_cox.pdf (accessed on 29 May 2015).

32. Wenger, E.; McDermott, R.; Snyder, W.M. Cultivating Communities of Practice; Harvard Business School Press: Boston, MA, USA, 2002.

33. Wenger, E. Communities of Practice: Learning, Meaning and Identity; Cambridge University Press: Cambridge, MA, USA, 1998.

34. Environment and School Initiative (ENSI). ENSI Explanatory Memorandum; Enschede: The Netherlands, 2006.

35. Interviewed by Michael Duggan. Brisbane, Australia. Skype Interviewee \#8 of ENSI Country Coordinator. 16 April 2012.

36. Environment and School Initiative (ENSI). Constritution of ENSI-Environment and Schools Initiatives i.n.p.a. Accredited by Royal Belgian Decree. Available online: http://www.ensi. org/About_ENSI/Constitution/Organizational_structure/ (accessed on 29 May 2015).

37. Veugelers, W.; O’Hair, M.J. Network Learning for Educational Change; Open University Press, McGraw-Hill: Berkshire, UK, 2005.

38. Cummings, S.; van Zee, A. Communities of practice and networks: Reviewing two perspectives on social learning. Knowl. Manag. Dev. J. 2005, 1, 8-22.

39. Vann, K.; Bowker, G.C. Instrumentalizing the truth of practice. Epistemology 2001, 15, 247-262.

40. Rauch, F.; Schrittesser, I. Networks as Support Structure for Quality Development in Education. ENSI-Series 17; CIDREE Collaborative Project: Klagenfurt, Germany, 2003.

41. Glasser, H. An Early Look at Building a Social Learning for Sustainability Community of Practice: RCE Grand Rapids, Flagship Project. J. Educ. Sustain. Dev. 2010, 4, 61-72. 
42. Cox, A. What are Communities of practice? A comparative review of four seminal works. J. Inf. Sci. 2005, 31, 527-540.

43. Organization of Economic Cooperation and Development (OECD). Evaluating Innovation in Environmental Education; Somekh, B., Pettigrew, M., Eds.; OECD: Paris, France, 1994; pp. 1-186.

44. Interviewed by Michael Duggan. Brisbane, Australia. Skype Interviewee \#15 of ENSI Pedagogical Coordinator/Critical Friend. 20 August 2012.

45. Interviewed by Michael Duggan. Brisbane, Australia. Skype Interviewee \#9 of ENSI Country Coordinator/Secretariat. 13 March 2012.

46. Interviewed by Michael Duggan. Brisbane, Australia. Skype Interviewee \#4 of ENSI Project Manager/Secretariat. 28 March 2012.

47. Warburton, K. Deep learning and education for sustainability. Int. J. Sustain. High. Educ. 2003, 4, 44-56.

48. Pfaffenwimmer, G.; Smith, S. The OECD/CERI decentralised network Environment and Schools Initiatives: A Reflection on Networking Experiences. 2000. Available online: http://www.fsifee.ugakugei.ac.jp/apreen/reports/4th/4RESOURCE1.html (accessed on 29 May 2015).

49. Schaltegger, S.; Wagner, M. Sustainable entrepreneurship and sustainability innovation: Categories and interactions. Bus. Strat. Environ. 2010, 20, 222-237.

50. Colucci-Gray, L.; Camino, E.; Barbiero, G.; Gray, D. From Scientific Literacy to Sustainability Literacy: An Ecological Framework for Education. Sci. Educ. 2006, 90, 227-252. Available online: http://www.interscience.wiley.com (accessed on 20 October 2014).

51. Edwards, M.; Gaventa, J. Global Citizen Action; Earthscan: London, UK, 2001.

52. Wilson-Grau, R.; Nunez, M. Evaluating International Social Change Networks: A Conceptual Framework for a Participatory Approach. Dev. Pract. 2006, 17, 258-271.

53. Davies, L. Comparing Definitions of Democracy in Education. Compare J. Compar. Int. Educ. 1999, 29, 127-140.

54. Posch, P. The Beginnings of ENSI. ENSI, 2011. Available online: http://www.ensi.org/About_ ENSI/Main_issues/ (accessed on 13 December 2014).

55. Posch, P. Networking in Environmental Education; Pettigrew, M., Somekh, B., Eds.; OECD: Paris, France, 1994; pp. 61-87.

56. Huckle, J. Environmental education and sustainability: A view from critical theory. In Environmental Education: A Pathway to Sustainability; Fien, J., Ed.; Deakin Unversity: Burwood, Australia, 1993; pp. 43-68.

57. Lauglo, J. Forms of Decentralisation and Their Implications for Education. Compar. Educ. 1995, 31, 5-30.

58. Sorkaa, A. Democratic values and limitation of local government reforms. In Democratic Experiment in Nigeria-Interpretive Essays; Oyovbaire, S., Ed.; Omega Publishers: Benin, Nigeria, 1987.

59. Buckler, C.; Creech, H. Shaping the Future We Want: UN Decade of Education for Sustainable Development (2005-2014) Final Report; United Nations Educational, Scientific and Cultural Organization (UNESCO): Paris, France, 2014.

60. Burkhardt, H.; Schoenfeld, A.H. Improving educational research: Toward a more useful, more influential, and better-funded enterprise. Educ. Res. 2003, 32, 3-14. 
61. Altrichter, H.; Posch, P. Teachers Investigate Their Work-An Introduction to the Methods of Action Research; Routledge: London, UK; New York, NY, USA, 1993.

62. Interviewed by Michael Duggan. Brisbane, Australia. Skype Interviewee \#10 of ENSI Project Manager. 10 September 2012.

63. Interviewed by Michael Duggan. Brisbane, Australia. Skype Interviewee \#6 of ENSI Secretariat. 14 March 2012.

64. Nambiar, P. Developing Learning Opportunities for Sustainability. J. Educ. Sustain. Dev. 2014, 8, 87-88.

65. Brody, M.; Hug, J.W. NAAEE Communicator. North American Association for Environmental Education. Winter 2005, 35, 1-11.

66. Nyden, P.; Wiewel, W. Collaborative research: Harnessing the tensions between researcher and practitioner. Am. Sociol. 1992, 23, 43-55.

67. Tilbury, D. Environmental education for sustainability: Defining the new focus of environmental education in the 1990s. Environ. Educ. Res. 1995, 1, 195-212.

68. Hargreaves, A. Sustainability of Educational Change: The Role of Social Geographies. J. Educ. Change 2002, 3, 189-214.

69. Ibarra, R. Context Diversity: Reframing Higher Education in the 21st Century. In A More Perfect Vision: The Future of Campus Engagement; Holland, B., Meeropol, J., Eds.; Campus Compact: Boston, MA, USA, 2006.

70. Elliott, J. Environmental Education and School Initiatives: Implications for the Curriculum in Basic Education; University of East Anglia: Norwich, UK, 1996.

71. Ryan, E. Sustainable Schools Going Global: An Exploration of Implementing "Eco-Schools" in a Local Cross-Cultural Context. Ph.D. Thesis, Griffith University, South East Queensland, Australia, 6 October 2011.

72. Sauvé, L.; Berryman, T. Challenging a "Closing Circle”: Alternative Research Agendas for the ESD Decade. Appl. Environ. Educ. Commun. 2005, 4, 229-232.

73. Sauvé, L.; Brunelle, R.; Berryman, T. Influence of the Globalized and Globalizing Sustainable Development Framework on National Policies Related to Environmental Education. Policy Fut. Educ. 2005, 3, 271-283.

74. Centre for Educational Research and Innovation (CERI). Environment and School Initiatives: Proposal by the Austrian Authorities; Doc.Nr. CERI/CD (86)11; OECD CERI: Paris, France, 1986.

75. Massarsky, C.W.; Gillespie, J.F. The State of Scaling Social Impact: Results of a National Study of Non-Profits; Growth Philanthropy Network: New York, NY, USA, 2013.

76. Interviewed by Michael Duggan. Brisbane, Australia. Skype Interviewee \#12 of FEE Board Member. 23 August 2012.

77. Margoluis, R.; Salafsky, N. Measures of Success: Designing, Managing, and Monitoring Conservation and Development Projects; Island Press: Washington, DC, USA, 1986.

78. Tilbury, D. Monitoring and Evaluation during the UN Decade of Education for Sustainable Development. J. Educ. Sustain. Dev. 2007, 1, 239-254.

79. Tilbury, D. Tracking Our Progress: A Global Monitoring and Evaluation Framework for the UN-DESD . J. Educ. Sustain. Dev. 2009, 3, 189-193. 
80. Tilbury, D. Assessing ESD Experiences During the UN-DESD: An Expert Review on Processes of Learning for ESD; United Nations Educational, Scientific and Cultural Organization: Paris, France, 2010.

81. Bellamy, J.; Smith, T.; Taylor, B.;Walker, M. Regional natural resource management planning arrangements: evaluating through the regional lens. In Regional Natural Resource Management Planning: The Challenges of Evaluation as Seen through Different Lenses; Bellamy, J., Ed.; Science Communications Unit, Natural Resource Sciences, Department of Natural Resources and Mines: Queensland, Australia, 2004; pp. 27-34.

82. Stem, C.; Margoluis, R.; Salafsky, N.; Brown, M. Monitoring and Evaluation in Conservation: A Review of Trends and Approaches. Conserv. Biol. 2005, 19, 295-309.

83. Klauer, B.; Drechsler, M.; Messner, F. Multicriteria analysis under uncertainty with IANUS-method and empirical results. Environ. Plann. C: Govern. Policy 2006, 24, 235-256.

84. United Nations Educational, Scientific and Cultural Organization (UNESCO). Roadmap for Implementing the Global Action Programme on Education for Sustainable Development; UNESCO: Paris, France, 2014.

(C) 2015 by the authors; licensee MDPI, Basel, Switzerland. This article is an open access article distributed under the terms and conditions of the Creative Commons Attribution license (http://creativecommons.org/licenses/by/4.0/). 